\title{
Unilateral exophthalmos in a horse - Diagnosis, management and outcome
}

\author{
Astrid Bienert-Zeit', Eva Nordemann', Myriam von Borstel', Peter Wohlsein², Maximilian Iseringhausen², Maren Hellige and Anna \\ Rötting ${ }^{l}$ \\ ${ }^{1}$ Clinic for horses, University of Veterinary Medicine Hannover, Germany \\ 2 Institut for Pathology, University of Veterinary Medicine Hannover, Germany
}

\begin{abstract}
Summary
A 19-year-old Arabian mare was presented in the equine clinic with a history of a slowly progressing exophthalmos during six months without impairment of her general condition and vision. Using ophthalmoscopy and ultrasonography there were no morphologic changes of the bulbus. A retrobulbar mass of soft tissue density deformed the bulbus and pushed it out of the orbital cavity. The dimensions of the neoplastic growth were exactly determined using magnetic resonance imaging. The retrobulbar mass was surgically removed via dorsal orbitotomy and a melanoma was diagnosed histologically. No complications arose afterwards. The visus could be preserved. The upper eyelid still showed a partial ptosis six months after surgery.
\end{abstract}

Keywords: ophthalmology / magnet resonance tomography /ultrasonography / orbit / eye / tumor / retrobulbar melanoma / orbitotom / ophthalmology / MRI

Correspondence: Dr. Astrid Bienert-Zeit, Clinic for horses, University of Veterinary Medicine Hannover, Bünteweg 9, 30559 Hannover, Germany. E-Mail: Astrid.Bienert@tiho-hannover.de

Citation: Bienert-Zeit A., Nordemann E., von Borstel M., Wohlsein P., Iseringhausen M., Hellige M., Rötting A. (2014) Unilateral exophthalmos in a horse - Diagnosis, management and outcome. Pferdeheilkunde 30, 81-90

\section{Introduction}

Exophthalmos is a rare condition in the horse. It has been defined as a dislocation of a normally sized bulbus out of the orbita caused by a retrobulbar mass (Barnett et al. 1988, Brooks und Matthews 2007, Gilger 2011 1). An exophthalmos is also known under the term Protrusio bulbi. Clinical signs can include epiphora, chemosis, ceratopathies and loss of vision through compression of the optical nerve in addition to the obvious protrusion of the bulbus (Barnett et al. 1988). Occasionally the bulbus appears hard upon palpation and an increased intraocular pressure is noted (Scotty et al. 2004). Protrusion of the third eyelid can also be present but is more common in cases with enophthalmos.

An exophthalmos must be differentiated from cases with buphthalmos or hydrophthalmos were the bulbus itself is enlarged (Scotty et al. 2004, Gilger und Stoppini 201 1). Additional findings in bupthalmos and hydrophthalmos are: increased intraocular pressure, mydriasis, diffuse corneal edema, tears of the Descemet membrane (Haabsche lines), and episcleral and conjunctival hyperaemia. If none of these signs are noted an exophthalmos is more likely (Scotty et al. 2004). In this article the diagnostic and therapeutic approaches in an older grey mare with unilateral exophthalmos are described.

\section{Case report}

Case history

A 19-year old Arabian half-blood mare was presented to the Clinic for horses of the Veterinary University of Hannover for diagnosis and treatment of unilateral left protrusion of the bulbus. Approximately 6 months prior to presentation a laceration of the lower left eyelid was noted and healed without complications. A few weeks later a protrusion of the left eyelid was noted. According to the owner the protrusion developed within a short time period and remained unchanged over the following months.

\section{Clinical Examination}

Upon presentation the mare was bright, alert and responsive. Severe exophthalmos of the left eye (Fig. 1) and a mild soft swelling over the left supraorbital fossa were present. In addition an approximately $1 \times 1 \mathrm{~cm}$ firm pigmented and non-painful mass was noted on the ventral side of the tail. A hematological examination revealed no abnormalities. Upon ophthalmological examination bilaterally a positive menace reflex, a positive pupillary reflex and complete eyelid closure exist. In the left eye a prolapse of the third eyelid and injection of the episcleral vessels were seen (Fig. 1). The bony orbita showed no abnormalities upon palpation and was not painful.

\section{Diagnostic imaging}

Ultrasonography

For ultrasonographic examination of the left eye and its surrounding structures a linear probe (Logic E9, GE Healthcare Company) was used in B-mode. A retrobulbar mass with a capsule and an inhomogenous structure was visualized that resulted in deformation of the bulbus (Fig. 2). The mass could not be imaged completely but was at least $4 \times 3.5 \mathrm{~cm}$ 
in size in a lateral to lateral direction. No other morphological changes were seen in the bulbus.

Magnetic resonance imaging

Based on clinical and ultrasonographical examinations a retrobulbar tumor mass was suspected. Magnetic resonance imaging was performed for an exact determination of the extent and the tissue character of the mass. The horse was placed in dorsal recumbency under general anesthesia and a 3 Tesla magnetic resonance scanner (Achieva ${ }^{\circledR}$, Philips Electronics, The Netherlands) was used. Four connected flexible spools were positioned around the scull and the following sequences were measured:

- T1 3D with and without contrast medium (KM)

- T2 (TSE) transverse, coronal and sagital

- T2 (FFE) HEMO (T2*) transverse

- T2 FLAIR transverse

The retrobulbar mass appeared to have a central indentation in all sequences and had no direct connections with the sur-

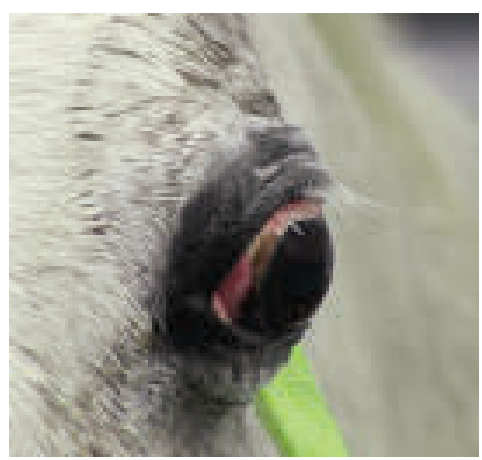

Fig. 1 Unilateral exophthalmos in a grey horse. The affected eye demonstrates no signs of pain, only injection of the conjunctiva and a prolapse of the third eyelid are found. / Unilateraler Exophthalmus bei einem Schimmel. Der betroffene Bulbus zeigt keinen Abwehrtrias, lediglich die Konjunktivalgefäße sind vermehrt injiziert und das dritte Augenlid ist vorgefallen.

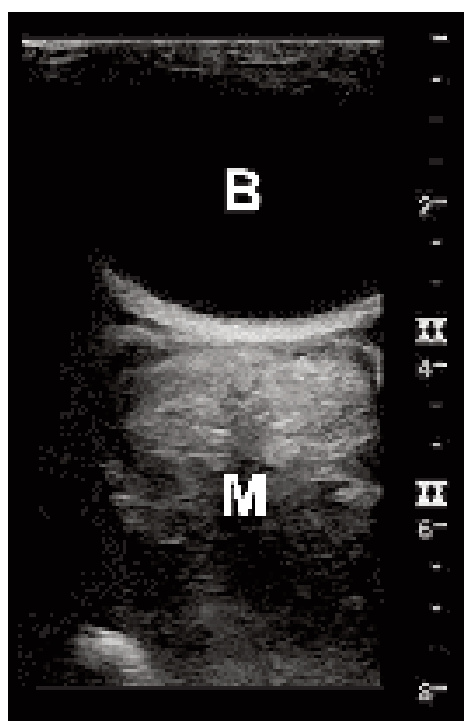

Abb. 2 Transpalpebral ultrasonography of the affected eye (B) revealing a retrobulbar mass (M). The globe is mildly flattened. Transpalpebrale Ultrasonographie des betroffenen Bulbus (B) mit einer retrobulbär gelegenen Umfangsvermehrung (M). Der Bulbus ist geringgradig verformt bzw. abgeflacht. rounding tissues. In the T2 sequences the mass appeared to consist of two parts with different signal intensities. The abaxial positioned hypointense part seemed to protrude from the axially positioned part that was isointense when compared to muscular tissue (Fig. 3 a). The measured size of the mass was $4.5 \times 5.0 \times 5.0 \mathrm{~cm}$ (Fig. 3c). The part of the mass immediately adjacent to the eye appeared to have a close connection with the zygomatic process of the frontal bone (Figs. 3a and 3b, arrow). A direct association between the mass and the optical nerve, retrobulbar fat or muscle could not be seen. In the T1 sequence the mass appeared inhomogeneous and hyperintense (Fig. 3b).
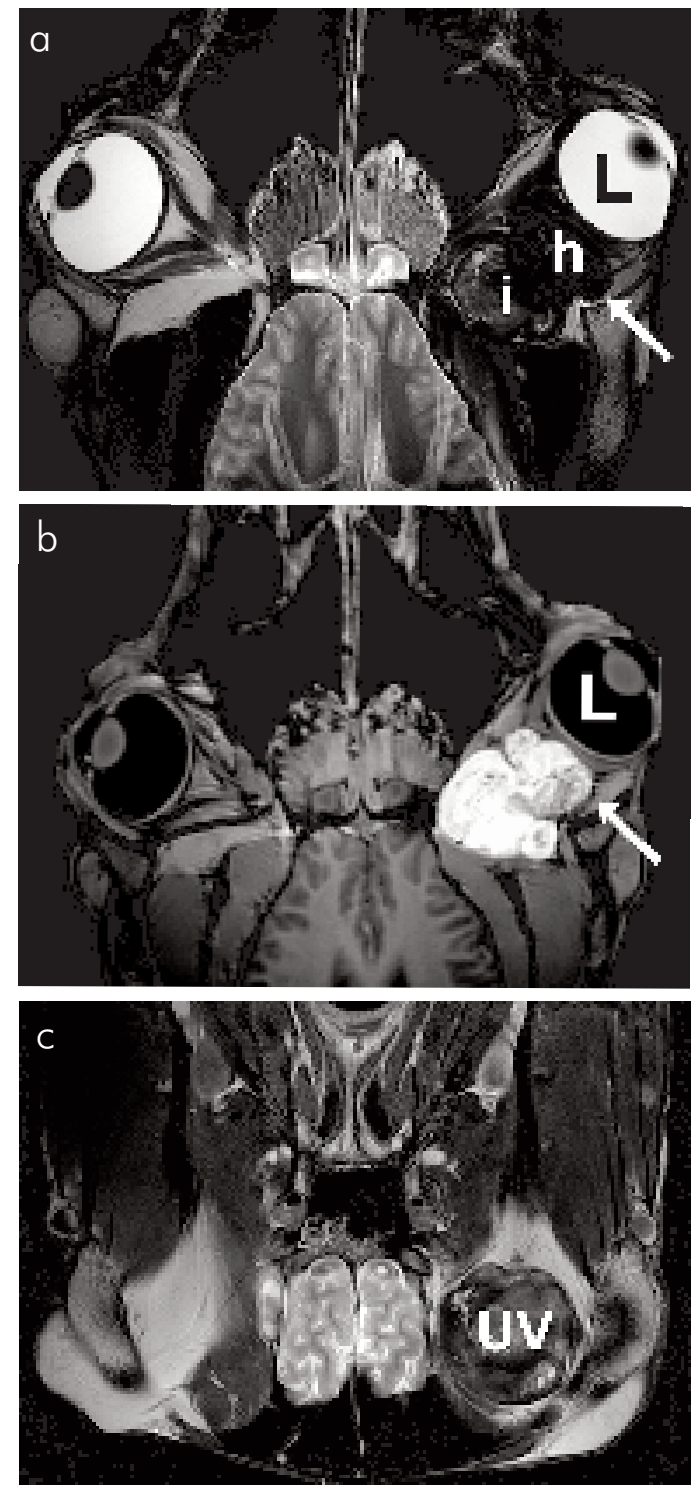

Abb. 3a, b und c MR image of the head of the horse. Dorsal T2w (a) and TIw (b) show a lobulated neoplasia behind the left bulb (L). The mass (UV) consists of two different intensities (h and i) and forces the bulb rostrally. The abaxial part of the mass is in close communication to the bone (arrow). Transversal T2w (c) demonstrate the enlargement of the inhomogeneous mass surrounded by a capsule. MRT-Aufnahmen des Kopfes des betroffenen Pferdes. Dorsale T2w (a) und TIw (b) mit lobulierter Neoplasie retrobulbär des linken Auges (L). Die Umfangsvermehrung (UV) weist zwei unterschiedliche Intensitäten (h und i) auf und verlagert den Bulbus nach rostral. Der abaxiale Anteil der UV steht in enger Assoziation mit dem Knochen (Pfeil). In der transversalen T2w (c) ist die Ausdehnung der UV zu erkennen. Sie ist inhomogen und von einer Kapsel umgeben. 
After intravenous application of the contrast medium gadoteric acid $\left(0.1 \mathrm{mmol} / \mathrm{kg}\right.$ bwt, Dotarem ${ }^{\circledR} 0.5 \mathrm{mmol} / \mathrm{ml}$ injection fluid, Guerbet $\mathrm{GmbH}$, Sulzbach/Taunus) only mild uptake in the outer parts of the mass was noted.

\section{Biopsy}

A true cut biopsy of the mass was harvested under ultrasonographic control through the left supraorbital fossa. For this purpose a Rotex Screw Needle Biopsy Instrument ${ }^{\circledR}$ (Ursus Konsult $A B$, Stockholm, Sweden) was used in a depth of approximately $8 \mathrm{~cm}$. Harvested tissue was fixed in $10 \%$ formalin and submitted for histopathological examination. A diagnosis of melanocytic neoplasia was made.

\section{Surgical approach}

For removal of the retrobulbar mass an orbitomy as described by Basher et al. (1997) was performed under general anesthesia. For this purpose the mare was positioned in right lateral recumbency and the surgical site was clipped and prepared for aseptic surgery with povidone-iodine soap (Jodosept-Gel ${ }^{\circledR}$, Vétoquinol, Ravensburg) and sterile saline solution ( $\mathrm{NaCl}$-Lösung 0,9\%, B. Braun Melsungen AG).

The skin over the supraorbital fossa next to the zygomatic arch was incised semicircular over a length of about $7 \mathrm{~cm}$ and electrocautery was used to achieve hemostasis. This resulted in exposure of the retrobulbar fat pad which was bluntly dissected. Underneath the fat pad a black lobular mass surrounded by a transparent capsule was identified (Fig. 4). The 2 parts of the melanoma that were identified during magnetic resonance imaging could be differentiated upon palpation. The mass appeared to have a firm to soft and elastic consistency. The first, firmer, part of the mass could be bluntly separated from the surrounding tissues and exteriorized into the surgical field. The second, softer, part of the mass was firmly attached to the zygomatic process of the frontal bone and required sharp dissection during which this

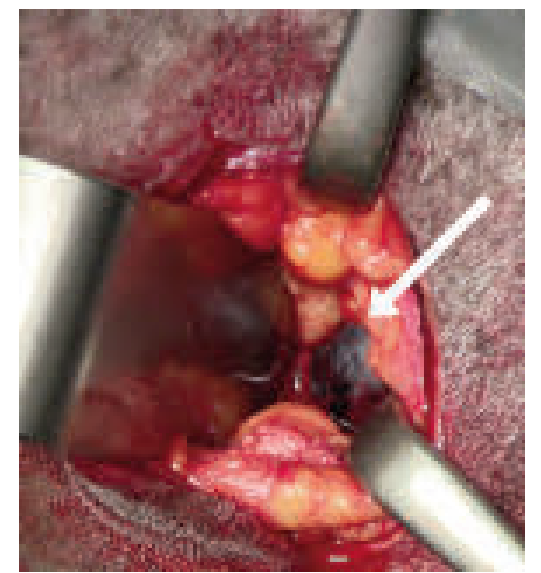

Abb. 4 Intraoperativ view. After preparation of skin and subcutis the retrobulbar fatty tissue was kept aside. Part of the capsule of the abaxial part of the melanoma (arrow) was visible (left).

Intraoperativer Situs. Nach vollständiger Eröffnung von Haut und Unterhaut wird das retrobulbäre Fett mit stumpfen Wundhaken zur Seite gehalten, so dass Anteile der Kapsel des abaxialen Anteils des Melanoms (Pfeil) sichtbar werden. part of the mass ruptured. The second part of the mass was removed in multiple sections. As a result the remaining tissues in the surgical field were stained black.

Immediately following removal of the mass the bulbus returned to its normal position. The surgical field was copiously flushed with sterile saline solution. Before wound closure $10 \mathrm{ml} 5$-fluorouracile $\left(5\right.$-FU Hexal ${ }^{\circledR} 50 \mathrm{mg} / \mathrm{ml}$ injection fluid $5.000 \mathrm{mg}$, Hexal AG, Holzkirchen) was applied into the surgical field. Skin and subcutaneous tissue were closed with resorbable suture material $\left(V_{i c r y}{ }^{\circledR}\right.$ 2-0, Ethicon, Norderstedt) in a simple continuous fashion. A bandage covering the wound and the left eye was applied before allowing the horse to recover from anesthesia. The mass was fixed in $10 \%$ formalin and submitted for histopathological examination.

\section{Pathohistology}

Tissue sections were routinely stained with hematoxylin and eosin and subsequently bleached with hydrogen peroxide. Sections consisted of a dense population of proliferated melanocytic cells surrounded by a fibrous capsule in most parts (Fig. 5, above). Tumor cells were predominantly organized in strands or nests and had a fusiform or occasionally a polygonal shape. The round to oval nuclei contained fine
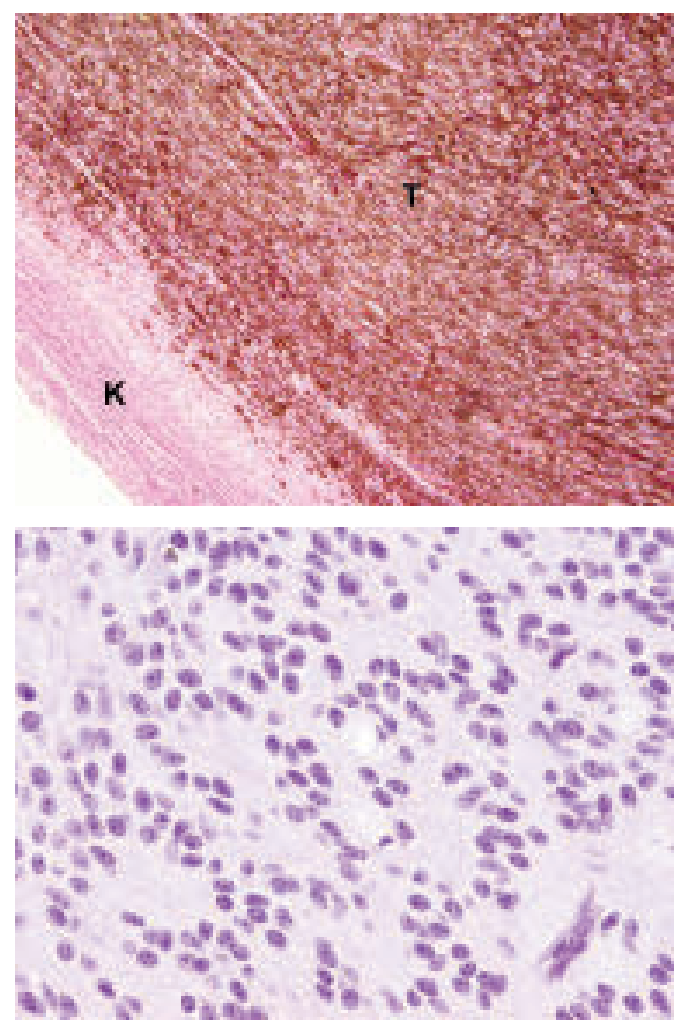

Abb. 5 Histology of the retrobulbar melanoma: The severely pigmented neoplastic growth $(T)$ is surrounded by a fibrous capsule $(K)$ $\mathrm{HE}, 10 \times$ (above). The retrobulbar melanoma is composed of a monomorphic tumour cell population; staining: haematoxylin and eosin and bleaching with $\mathrm{H}_{2} \mathrm{O}_{2}, 40 \times$ (below).

Histologie des retrobulbären Melanoms: Die stark pigmentierte Umfangsvermehrung (T) ist umgeben von einer bindegewebigen Kapsel (K); HE, $10 \times$ (oben). Das retrobulbäre Melanom setzt sich aus einer monomorphen Tumorzellpopulation zusammen; HE und Bleichen mit $\mathrm{H}_{2} \mathrm{O}_{2}, 40 \times$ (unten). 
granular heterochromatine and a predominantly small single nucleolus (Fig. 5, below). In the cytoplasm a large amount of fine black to brown melanin granules were seen. Mitotic figure were rare $(<1$ mitotic figure/ 20 visual fields viewed through a $40 x$ objective). Clusters of large macrophages with much cytoplasm and large amounts of pigments (melano-macrophages) were seen multifocal.

\section{Outcome}

The mare was treated with antimicrobial and antiphlogistic medications for 8 days following surgery and made an uneventful recovery. The bandage was removed the day following surgery and the exophthalmos had completely resolved. The upper eyelid of the left eye showed a mild chemosis and moderate ptosis. The menace reflex and pupillary reflexes were positive. The surgical wound was well adapted, dry and had only a mild edema. 7 days after surgery the mare was discharged from the hospital. 6 months later the mare was presented for a recheck examination. She was bright, alert and responsive and the left eye functioned without abnormalities with the exception of a partial ptosis of the upper eyelid. The mare could lift the medial aspect of the upper eyelid completely.

\section{Discussion}

The horse in the present case was presented to our clinic because of a protruding left eyeball. Clinical and ultrasonographic examinations were used to differentiate between an exophthalmos caused by a retrobulbar mass and a primary disease of the eyeball itself. Latter would be named buphthalmos and can be the result of chronic glaucoma (Gilger and Stoppini 2011 ). In the present case no pathologic changes of the eyeball were found and the diagnosis of exophthalmos was made.

An exophthalmos can have several causes that can originate in the orbita or the paranasal sinuses. It is considered a lead symptom of retrobulbar masses (Tóth an Hollerrieder $2010 b)$. Retrobulbar tumours are rare in horses, and are the most frequent cause of an exophthalmos (Matiasek et al. 2007). In the present case inflammatory disease was considered unlikely because the mare was non-painful upon palpation. The owners of the mare had reported an eyelid laceration shortly before they first noticed the exophthalmos and suggested a causal connection. However, it appears highly unlikely that the eyelid laceration influenced the protrusion of the eyeball in this case.

Several diagnostic modalities and procedures are available to evaluate a horse with exophthalmos and should always begin with a general clinical examination followed by an ophthalmologic evaluation. In the present case this was followed by an ultrasonographic examination to evaluate the retrobulbar soft tissue structures (Mettenleiter 1995, Tóth and Hollerrieder 2010a). However, ultrasonography has been considered to have a low specificity and sensitivity for this purpose (Gilger 2011 ). Ultrasonography can estimate contour and structure of a retrobulbar mass, but the exact location and extent of a tumor can often not be seen with this diagnostic modality (Miller and Cartee 1985, Matiasek et al. 2007), as was the case in this patient. Radiography can image radiodense structures in the ocular region, but overlapping structures limit its use in this anatomic area. In select cases with more radiodense changes there can be some value of radiography (Tóth and Hollerrieder 2010a), but in the present case ultrasonography had identified a retrobulbar soft tissue mass and radiography was not considered to have additional benefits.

Further useful imaging modalties for cases similar to the one presented include computertomography and magnetic resonance imaging. Both modalities provide images of various tissue levels, allowing a precise evaluation of anatomical regions without overlapping structures. In this way additional information about the localization and extent of a retrobulbar mass can be obtained which may influence the subsequent therapeutic approach (Wollanke et al. 2006). Magnetic resonance imaging is particularly useful for soft tissue imaging (Arencibia et al. 2000, Gerlach and Gerhards 2008). Before any surgical approach an involvement of optical nerve, eyeball and bone should be ruled out in case of retrobulbar tumour masses (Matiasek et al. 2007). In the present case magnetic resonance imaging was performed using a 3 Tesla machine. Since none of the above structures were involved a surgical treatment sparing the eyeball was planned, and the approach was chosen considering the now know full extent of the retrobulbar mass.

Magnetic resonance imaging can in part characterize the structure of soft tissues (Wollanke et al. 2006, Gerlach and Gerhards 2008), but a differentiation between benign and malign tumours is seldom possible (Gerlach and Gerhards 2008). Gerlach et al. (2007) described magnetic resonance imaging in three horses with melanoma in the head region, one of which in a retrobulbar position. The melanoma in these horses had a higher signal intensity in $\mathrm{T} 1$-weighted sequences and a lower signal intensity in T2-weighted sequences. The authors concludes that this would allow a differentiation of masses as melanoma based on magnetic resonance imaging. However, the described imaging characteristics were not completely applicable to the horse in the present report, in particular because the signal intensity in the T2-weighted sequences was inhomogeneous. Human literature describes various magnetic resonance imaging patterns of melanoma (Hammersmith et al. 1990, Isiklar et al. 1995). Therefor a tentative diagnosis of melanoma based on magnetic resonance imaging should be verified. For a definite diagnosis histophathological examination is the method of choice (Basher et al. 1997, Gilger 2011). For this reason in the present case a needle biopsy specimen of the mass was obtained immediately after magnetic resonance imaging under ultrasonographic control. The mechanical irritation caused by needle biopsies of a melanoma can result in a stimulation of abnormal melanocytes or in transposition of tumor cells into healthy tissues. A subsequent new tumor growth is possible (Pascoe and Knottenbelt 1999). For this reason these risks should be weighed against the potential benefits before this manipulation and the owners should be informed. However, only histopathological examination allows for an exact diagnosis and a differentiation from other neoplastic diseases such as neuroendocrine carcinoma. The latter is one of the most common tumors of the orbita in the 
horse (Gilger 2011 ) and carries a guarded prognosis because of a potential spread to the cerebrum, leading to neurologic disease and a poor prognosis (Wollanke et al. 2006). Therefor in the present case the potential benefits of a needle biopsy were considered to outweigh the potential risks.

The histopathology verified the diagnosis of a benign neoplasia of the melanocytes with a noninvasive growth. Melanoma of melanocytoma is a skin tumor that can occur in several body regions. The orbita is considered to be an uncommon location (McMullen et al. 2008). Melanoma most frequently are seen in grey horses older than $6-8$ years and grow slowly (Pascoe and Knottenbelt 1999). The mare of the present report was an older grey horse with a darkly pigmented nodular mass underneath the tail that was most likely also a melanoma.

The authors have found only three reports of retrobulbar melanoma in the horse (Sweeney and Beech 1983, Wollanke et al. 2006, Gerlach et al. 2007). All horses were grey and older than 14 years. The slowly growing masses resulted in protrusion of retrobulbar fat in the fossa supraorbitalis and exophthalmos. Two of these three horses additional showed masseter swelling on the affected side. The diagnosis of melanoma was made after surgical removal (Wollanke et al. 2006, Gerlach et al. 2007) or examination of a biopsy specimen (Sweeney and Beech 1983). In the latter case no surgical removal of the melanoma was attempted and the ani$\mathrm{mal}$ presented with progression of the exophthalmos 26 months after initial evaluation. Visus, pupillary reflexes and menace response in that horse were still intact, but the number of retinal vessels had declined compared to the contralateral side. An expositional ceratopathy was present and was permanently being treated with antibiotic eye ointments (Sweeney and Beech 1983). An horse with retrobulbar melanoma can survive without surgical excision, but continuos growth of the tumor is likely and secondary complication can occur necessitating continuous medical care to allow early enough palliativ treatment.

In the present case surgical excision of the retrobulbar melanoma was achieved via a dorsal orbitotomy without osteotomy of the zygomatic arch. The approach chosen has been described by Basher et al. (1997) for removal of a retrobulbar neuroendocrine tumor. An osteotomy of the zygomatic arch has been suggested for removal of foreign bodies, tumors, cysts, and abscesses (Tóth and Hollerrieder 2010c, Gilger 2011 ). Risks of any orbitotomy include trauma to the eye or its adnexal structures and damage of branches of the auriculopalpebral nerve. Preoperative magnetic resonance imaging allows a more detailed planning of the surgical approach to minimize these risks and has been strongly recommended by Gilger (2011). The retrobulbar mass can distort adjacent anatomical structures and branches of the auriculopalpebral nerve can deviate from their expected location. Blunt tissue preparation techniques should be used during surgery to spare important anatomical structures.

The partial loss of upper eyelid function in the present case most likely is the result of damage to individual nerve branches through tension, pressure, manipulation or transection. Function of the upper eyelid is mostly achieved by two muscles: the levator palpebrae superioris innervated by the occulomotor nerve and the levator anguli oculi medialis innervated by the zygomatic branch of the auriculopalpebral nerve (Wissdorf et al. 2010). The latter muscle was likely not damaged in the present case because this muscle is responsible for lifting of the medial part of the eyelid, and this function was undisturbed in the horse of the present report. Therefor damage to the occulomotor nerve has likely occurred during surgical removal. This damage can be permanent or nerve function may return.

After surgery a risk of melanoma recurrence or metastasis remains and is increased because the tumor capsule ruptured during surgery and not all melanin cells could be removed. The ruptured part of the melanoma had been firmly attached to bone of the zygomatic process as had been suspected after magnetic resonance imaging. An alternative surgical approach including a temporary resection of parts of the zygomatic process and arch has been described (Goodhead et al. 1997), but would not have eliminated the risk of tumor rupture. Therefor the less invasive approach without osteotomy was chosen. Both remaining tumor cells and mechanical stimulation of abnormal melanocytes during surgery can result in new and fast tumor growth (Pascoe and Knottenbelt (1999). To prevent recurrence the surgical site was treated with 5 -fluorouracil.

\section{Literatur}

Arencibia A., Vázquez J. M., Jaber R., Gil F., Ramírez J. A., Rivero M., González N., Wisner E. R. (2000) Magnetic resonance imaging and cross sectional anatomy of the normal equine sinuses and nasal passages. Vet. Radiol. Ultrasound 41, 313-319

Barnett K. C., Cottrell B. D., Rest J. R. (1988) Retrobulbar hydatid cyst in the horse. Equine Vet. J. 20, 2, 136-138

Basher A. W. P., Severin G. A., Chavkin M. J., Frank A. A. (1997) Orbital neuroendocrine tumors in three horses. J. Am. Vet. Med. Assoc. 210, 668-671

Brooks D. E., Matthews A. G. R. (2007) Equine Ophthalmology. In: Gelatt K.N. (Hrsg.) Veterinary Ophthalmology. 5. Auflage. Blackwell, lowa, $1165-1274$

Gerlach K., Cronau M., McMullen R., Gerhards H. (2007) Magnetresonanztomographische Untersuchungen von Melanomen im Kopfbereich bei drei Pferden. Pferdeheilkunde 23, 3 259-262

Gerlach K., Gerhards H. (2008) Magnetresonanztomographische Merkmale von Zubildungen im Bereich der Nase, Nasennebenhöhlen und der angrenzenden Knochen: retrospektive Analyse von 33 Pferden. Pferdeheilkunde 24, 565-576

Gilger B. C. (2011) Diseases and Surgery of the Globe and Orbit. In: Gilger B.C. (Hrsg.) Equine Ophthalmology. 2. Auflage. Elsevier Saunders, Missouri, 93-132

Gilger B. C., Stoppini R. (2011) Equine Ocular Examination: Routine and Advanced Diagnostic Techniques. In: Gilger B.C. (Hrsg.) Equine Ophthalmology. 2. Auflage. Elsevier Saunders, Missouri, 1-28

Goodhead A. D., Venter I. J., Nesbit J. W. (1997) Retrobulbar extraadrenal paraganglioma in a horse and its surgical removal by orbitotomy. Vet. \& Comp. Ophthal. 7, 239-244

Hammersmith S. M., Terk M. R., Jeffrey P. B., Connolly S. G., Colletti P. M. (1990) Magnetic resonance imaging of nasopharyngeal and paranasal sinus melanoma. Magnet. Res. Imag. 8, 245-253

Isiklar I., Leeds N. E., Fuller G. N., Kumar A. J. (1995) Intracranial metastatic melanoma: correlation between MR imaging characteristics and melanin content. Am. J. Roentgenol. 165, 1503-1512

Matiasek K., Cronau M., Schmah/ W., Gerhards H. (2007) Imaging Features and Decision Making in Retrobulbar Neuroendocrine Tumours in Horses - Case Report and Review of Literature. J. Vet. Med. A 54, 302-306 
McMullen R. J., Clode A. B., Pandiri A. K. R., Malarkey D. E., Miller Michau T., Gilger B. C. (2008) Epibulbar melanoma in a foal. Vet. Ophthalmol. 11, 44-50

Mettenleiter E. M. (1995) Sonographische Diagnostik (B-mode-Verfahren) am Auge des Pferdes. Tierärzłl. Prax. 23, 588-95

Miller W. W., Cartee R. E. (1985) B-scan ultrasonography for the detection of space-occupying ocular masses. J. Am. Vet. Med. Assoc. 187, 66-68

Pascoe R. R. R., Knottenbelt D. C. (1999) Neoplastic Conditions. In: Pascoe R. R. R. und Knottenbelt D. C. (Hrsg.): Manual of Equine Dermatology. Saunders, New York, 241-279

Scotty N. C., Ford M., Williams III F., Loiacono C., Johnson P. J., Mes$\operatorname{ser}$ N. T., Turnquist S. E., Essman S. (2004) Exophthalmia associated with paranasal sinus osteoma in a Quarterhorse mare. J. Vet. Diagn. Invest. 16, 155-160

Sweeney C. R., Beech J. (1983) Retrobulbar melanoma in a horse. Equine Vet. J. Suppl. 2, 123-124

\section{Unilateraler Exophthalmus beim Pferd - Diagnostik, Therapie und Verlauf}

\begin{abstract}
Zusammenfassung: Bei einer 19-jährigen Araberstute hatte sich über annähernd sechs Monate ein Exophthalmus entwickelt, der zum Zeitpunkt der Vorstellung in der Klinik noch nicht zu einer Beeinträchtigung des Allgemeinbefindens oder des Sehvermögens geführt hatte. Der Bulbus war ophthalmoskopisch und ultrasonograpisch ohne pathologischen Befund. Durch eine retrobulbär gelegene, weichteildichte Masse war der Bulbus geringgradig deformiert und aus der Orbita gedrückt worden. Magnetresonanztomographisch wurde die exakte Ausdehnung der Neoplasie ermittelt. Die retrobulbäre Gewebezubildung wurde über eine dorsale Orbitotomie chirurgisch entfernt und histologisch als Melanom klassifiziert. Der postoperative Verlauf war komplikationslos. Das Sehvermögen des Auges blieb erhalten, lediglich das Oberlid zeigte auch Monate nach der Operation noch einen partiellen Funktionsverlust.
\end{abstract}

Schlüsselwörter: Ophthalmologie, Magnetresonanztomographie, Ultrasonographie, Orbita, Auge, Tumor, retrobulbäres Melanom, Orbitotomie

\section{Einleitung}

Ein Exophthalmus wird beim Pferd relativ selten beobachtet. Bei diesem Symptom handelt sich um eine Verlagerung eines normal großen Bulbus aus der Orbita aufgrund eines raumfordernden Prozesses (Barnett et al. 1988, Brooks und Matthews 2007, Gilger 2011 ). Er wird auch als Protrusio bulbi bezeichnet. Neben dem auffallend hervorstehenden Bulbus können Epiphora, Chemosis, Expositionskeratopathien und Visusverlust durch Kompression des Nervus opticus bestehen (Barnett et al. 1988). Gelegentlich werden auch ein palpatorisch auffällig harter Bulbus und ein erhöhter intraokularer Druck als Begleitsymptome beschrieben (Scotty et al. 2004). Ein Vorfall des dritten Augenlides kann ebenfalls vorkommen, dieser tritt jedoch häufiger bei einem Enophthalmus auf.

Der Exophthalmus muss vom Buphthalmus bzw. Hydrophthalmus differenziert werden, bei denen der Bulbus selbst vergröBert ist (Scotty et al. 2004, Gilger und Stoppini 2011). Der Buph- bzw. Hydrophthalmus zeichnet sich zusätzlich durch folgende Befunde aus: erhöhten intraokularen Druck, Mydriasis,
Tóth J., Hollerrieder J. (2010a) Untersuchung des Auges. In: Tóth J., Hollerrieder J. und Sótonyi P. (Hrsg.): Augenheilkunde beim Pferd. 1. Auflage. Schattauer, Stuttgart, 33-66

Tóth J., Hollerrieder J. (2010b) Neoplasien. In: Tóth J., Hollerrieder J. und Sótonyi P. (Hrsg.): Augenheilkunde beim Pferd. 1. Auflage. Schattaver, Stuttgart, 211-230

Tóth J., Hollerrieder J. (2010c) Operationen. In: Tóth J., Hollerrieder J. und Sótonyi P. (Hrsg.): Augenheilkunde beim Pferd. 1. Auflage. Schattaver, Stuttgart, 231-268

Wissdorf H., Otto B., Gerhards H. (2010) Nebenorgane des Auges. In: Wissdorf H., Gerhards H., Huskamp B. und Deegen E. (Hrsg.): Praxisorientierte Anatomie und Propädeutik des Pferdes. 3. Auflage. Schaper, Hannover, 91-111

Wollanke B., Gerhards H., Cronau M. (2006) Diagnostik und Therapie periorbitaler Erkrankungen von Pferden: Wann ist eine Computertomographie (CT) oder Magnetresonanztomographie (MRT) indiziert? Pferdeheilkunde 22, 431-438

diffuses Ödem der Kornea, Risse in der Descemetschen Membran, sog. Haabsche Linien, sowie episklerale und konjunktivale Hyperämie. Sofern diese Befunde nicht auftreten, ist eher ein Exophthalmus in Betracht zu ziehen (Scotty et al. 2004). Der vorliegende Artikel beschreibt und diskutiert das diagnostische und therapeutische Vorgehen am Beispiel einer älteren Schimmelstute, die mit einem einseitig aus der Orbita hervorstehenden Auge vorgestellt wurde.

\section{Fallbericht}

Anamnese

Bei dem Patienten handelte es sich um ein 19-jähriges arabisches Halbblutpferd. Die Schimmelstute hatte etwa ein halbes Jahr vor Klinikvorstellung eine Unterlidverletzung am linken Auge, die komplikationslos abheilte. Einige Wochen später entwickelte sich ipsilateral eine Vorwölbung des Augapfels. Diese entstand laut Besitzer innerhalb kurzer Zeit und zeigte sich im Folgenden über Monate unverändert. Die Stute wurde in der Klinik für Pferde der Stiffung Tierärztliche Hochschule Hannover zur Diagnostik und gegebenenfalls Therapie vorgestellt.

\section{Klinische Untersuchung}

Die Stute prösentierte sich mit ungestörtem Allgemeinbefinden. Es wurden ein hochgradiger Exophthalmus des linken Auges (Abb. 1) und eine geringgradig vermehrte, palpatorisch weiche Vorwölbung über der Fossa supraorbitalis festgestellt. Zusätzlich lag an der Unterseite der Schweifrübe eine ca. $1 \times 1 \mathrm{~cm}$ große, derbe, pigmentierte und nicht dolente Umfangsvermehrung vor. Die hämatologische Untersuchung erbrachte keine Werte außerhalb der Referenzbereiche. Im Rahmen der speziellen ophthalmologischen Untersuchung, zeigte die Stute bilateral eine positive Drohantwort, einen positiven Pupillarreflex sowie einen vollständigen Lidschluss. Am linken Auge bestand ein Vorfall des dritten Augenlides und die Episkleralgefäße waren vermehrt injiziert (Abb. 1). Palpatorisch wies die knöcherne Orbita keine Auffälligkeiten auf und war nicht druckdolent.

\section{Bildgebende Verfahren}

Ultrasonographie

Die ultrasonographische Untersuchung des linken Auges und der umgebenden Strukturen wurde im B-Mode-Verfahren mit 
einer Linearsonde (Logic E9, GE Healthcare Company) durchgeführt. Es wurde retrobulbär ein raumfordernder Prozess dargestellt, der den Bulbus deformierte, eine Kapsel sowie eine inhomogene Weichteilstruktur aufwies (Abb. 2). Er hatte mindestens eine latero-laterale Ausdehnung von $4 \times 3,5 \mathrm{~cm}$, ließ sich jedoch ultrasonographisch nicht zu allen Seiten hin abgrenzen. Der Bulbus wies bis auf die Protrusion keine morphologischen Veränderungen auf.

\section{Magnetresonanztomographie}

Auf der Basis der vorangegangenen Untersuchungen und des Vorberichtes wurde der Verdacht auf eine retrobulbäre Neoplasie gestellt. Zur genaueren Identifizierung der Ausdehnung Therapieund des Gewebecharakters der Zubildung wurde eine magnetresonanztomographische Untersuchung mit einem 3 Tesla-Kernspintomographen $\left(\right.$ Achieva $^{\circledR}$, Philips Electronics, Niederlande) in Rückenlage unter Allgemeinanästhesie durchgeführt. Vier miteinander verbundene, flexible Spulen wurden um den Schädel positioniert und folgende Sequenzen erstellt: T1 3D mit und ohne Kontrastmittel (KM), T2 (TSE) transversal, koronar und sagittal, T2 (FFE) HEMO (T2*) transversal sowie T2 FLAIR transversal.

Die retrobulbäre Umfangsvermehrung stellte sich in allen Sequenzen mit einer zentralen Einschnürung und ohne direkte Verbindung mit dem umliegenden Weichteilgewebe dar. In den T2-Sequenzen entstand der Eindruck, dass zwei unterschiedlich signalintense Anteile vorlagen, von denen sich das abaxiale, hypointense aus dem axial gelegenen Areal (isointens zur Muskulatur) pilzförmig hervorwölbte (Abb. 3a). Insgesamt hatte die Umfangsvermehrung eine Größe von ca. 4,5 ×5,0 ×5,0 cm (Abb. 3c). Der direkt hinter dem Auge liegende Anteil der Umfangsvermehrung stand lateral in enger Verbindung mit dem Processus zygomaticus des Os frontale (Abb. 3a und b, Pfeil). Eine direkte Assoziation mit dem Nervus opticus, dem retrobulbären Fettgewebe oder der Muskulatur wurde nicht nachgewiesen. In der T1-Sequenz stellte sich die Raumforderung inhomogen und hyperintens (Abb. 3b) dar.

Nach intravenöser Applikation des Kontrastmittels Gadotersäure $\left(0,1 \mathrm{mmol} / \mathrm{kg} \mathrm{KGW}\right.$, Dotarem ${ }^{\circledR} 0,5 \mathrm{mmol} / \mathrm{ml}$ Injektionslösung, Guerbet $\mathrm{GmbH}$, Sulzbach/Taunus) wurde nur eine geringgradige Anreicherung im Randbereich des raumfordernden Prozesses erzielt.

\section{Biopsieentnahme}

Unter ultrasonographischer Kontrolle wurde über die linke Fossa supraorbitalis ein Bioptat der retrobulbären Neubildung gewonnen. Die Probenentnahme erfolgte mittels Rotex Screw Needle Biopsy Instrument ${ }^{\circledR}$ (Ursus Konsult AB, Stockholm, Schweden) in acht Zentimeter Tiefe. Das Biopsiematerial wurde in 10\%ige Formalinlösung überführt und histopathologisch ergaben sich Hinweise auf eine melanozytäre Neoplasie.

\section{Chirurgisches Vorgehen}

Zu Entfernung der retrobulbären Neoplasie wurde eine Orbitotomie in Allgemeinanästhesie durchgeführt (Basher et al. 1997). Die Stute wurde in rechte Seitenlage verbracht und das geschorene Operationsfeld mit PVP-Jodseife (Jodosept-Gel ${ }^{\circledR}$, Vétoquinol, Ravensburg) und steriler $\mathrm{NaCl}$-Lösung ( $\mathrm{NaCl}$ Lösung 0,9\%, B. Braun Melsungen AG) vorbereitet. Die Haut in der Fossa supraorbitalis wurde entlang des Arcus zygomaticus halbkreisförmig über eine Länge von ca. $7 \mathrm{~cm}$ eröffnet und vereinzelte Blutungen kauterisiert. Subkutan war der retrobulbäre Fettkörper sichtbar, der stumpf durchtrennt wurde. Unterhalb des Fettkörpers war eine schwärzliche, lobulierte Masse erkennbar, die von einer durchsichtigen Kapsel umgeben war (Abb. 4). Palpatorisch konnten die schon in der MRTUntersuchung nachgewiesenen zwei Abschnitte des Melanoms nachvollzogen werden. Die Konsistenz der gesamten Umfangsvermehrung war weich und elastisch. Der erste Abschnitt wurde unter Erhalt der Kapsel stumpf vom umgebenden Gewebe gelöst und vorgelagert. Die Kapsel des zweiten Abschnittes rupturierte während des Lösens der derben Verbindung zwischen Processus zygomaticus und Melanom. Daher wurde dieser Teil in multiplen Segmenten entfernt.

Direkt nach Entfernung des Melanoms wurde ein Zurückgleiten des Bulbus in die Orbita beobachtet. Im Folgenden wurde die Wundhöhle ausgiebig mit steriler $\mathrm{NaCl}$-Lösung gespült, und abschließend wurden $10 \mathrm{ml}$ des Zytostatikums 5-Fluorouracil (5-FU Hexal ${ }^{\circledR} 50 \mathrm{mg} / \mathrm{ml}$ Injektionslösung $5.000 \mathrm{mg}$, Hexal AG, Holzkirchen) in die Wundhöhle appliziert. Hauł und Unterhaut wurden mit resorbierbarem Nahtmaterial (Vicryl ${ }^{\circledR}$ 2-0, Ethicon, Norderstedt) und fortlaufender Kürschnernaht adaptiert. Als Wundabdeckung wurde ein Kopfverband angelegt, der das linke Auge einbezog.

\section{Pathohistologischer Untersuchungsbefund}

Die histologische Untersuchung von repräsentativen Proben des formalinfixierten Tumorresektates an Hämtoxylin und Eosin- (HE)-gefärbten sowie anschließend mittels $\mathrm{H}_{2} \mathrm{O}_{2}$ gebleichten Schnittpräparaten zeigte eine überwiegend durch eine bindegewebige Kapsel begrenzte, zellreiche und kompakte Proliferation melanozytärer Zellen (Abb. 5, links). Die Tumorzellen waren überwiegend strangartig oder in Nestern angeordnet. Sie zeichneten sich durch eine spindelförmige, seltener durch eine polygonale Gestalt aus. Die rundovalen Zellkerne enthielten feingranuläres Heterochromatin und meist einen kleinen solitären Nukleolus (Abb. 5, rechts). Im Zytoplasma war ein hochgradiger Gehalt an feinen schwarzbraunen Melaningranula vorhanden. Mitosefiguren wurden nur sehr selten beobachtet ( $<1$ Mitosefigur/20 Gesichtsfelder bei $40 \times$ Objektivvergrößerung). Multifokal waren nesterartige Ansammlungen großer zytoplasmareicher und hochgradig pigmentbeladener Makrophagen (Melanomakrophagen) vorhanden.

\section{Weiterer Verlauf}

Die Stute zeigte post operationem ein gutes Allgemeinbefinden. Medikamentös wurde sie über acht Tage chemotherapeutisch und antiphlogistisch versorgt. Der Kopfverband wurde am Tag nach der Operation entfernt. Ein Exophthalmus war nicht mehr vorhanden. Des Weiteren zeigte das Oberlid des linken Auges eine geringgradige Chemosis und eine mittelgradige Ptosis (Abb. 6). Die Drohantwort war positiv, und die Pupille zeigte bei Lichteinfall eine reaktive Miosis. Die Operationswunde wies eine gute Adaptation auf, war trocken und nur geringgradig ödematisiert. Sieben Tage post operationem wurde die Stute bei gutem Allgemeinbefinden aus der Klinik entlassen. Sechs Monate nach der Operation präsentierte sich die Stute mit ungestörtem Allgemeinbefinden und uneinge- 
schränkter Funktionsfähigkeit des linken Auges. Das Oberlid zeigte weiterhin eine partielle Ptosis, allerdings konnte der mediale Anteil des Oberlides vollständig angehoben werden.

\section{Diskussion}

Das in diesem Fallbericht vorgestellte Pferd wurde aufgrund eines einseitig aus der Orbita hervortretenden Auges vorgestellt. Durch die klinische und ultrasonographische Untersuchung wird als erstes differenziert, ob es sich tatsächlich um einen Exophthalmus handelt, der durch einen raumfordernden Prozess hinter dem Auge entstanden ist, oder ob der Bulbus selbst krankhaft vergrößert ist. Ein derartiger Buphthalmus kann beispielsweise in Folge eines chronischen Glaukoms auftreten (Gilger und Stoppini 2011). Bei der vorgestellten Stute waren keine pathologischen Befunde am Augapfel zu erheben, so dass die Vorwölbung des Bulbus auf einem Exophthalmus beruhte.

Der Exophthalmus ist ein Symptom, dessen Ursachen vielfältig sind und sowohl im Bereich der Orbita, als auch der Nasennebenhöhlen liegen können. Er gilt als Kardinalsymptom bei retrobulbären Tumoren (Tóth und Hollerrieder 2010b), die beim Pferd zwar sehr selten vorkommen, aber die häufigste Ursache für einen Exophthalmus sind (Matiasek et al. 2007). Erkrankungen entzündlicher Genese erschienen im vorliegenden Fall als Differentialdiagnose eher unwahrscheinlich, da die Stute bei der Palpation und während der transpalpebralen Sonographie keine Anzeichen für einen schmerzhaften Prozess zeigte. Die Besitzer der vorgestellten Stute berichteten von einer Lidverletzung, die kurz vor dem Exophthalmus aufgetreten war und sahen einen Zusammenhang zwischen beiden Ereignissen. Im vorliegenden Fall bestand aber mit hoher Wahrscheinlichkeit kein ursächlicher Zusammenhang zwischen Lidverletzung und dem Exophthalmus.

Das Spektrum diagnostischer Möglichkeiten beim Exophthalmus ist breit. Die Grundlage bilden die klinische Allgemeinuntersuchung und eine anschließende, spezielle ophthalmologische Untersuchung. In dem hier vorgestellten Fall wurde nach der speziellen, ophthalmologischen Untersuchung eine weiterführende, ultrasonographische Untersuchung angeschlossen. Diese ermöglicht grundsätzlich eine Visualisierung und Differenzierung der Weichteilstrukturen des retrobulbären Bereiches (Mettenleiter 1995, Tóth und Hollerrieder 2010a), der sich der klinischen Allgemeinuntersuchung, speziellen Augenuntersuchung und der ophthalmoskopischen Untersuchung entzieht. Im Vergleich zu anderen Untersuchungsmethoden, zum Beispiel einer computertomographischen und magnetresonanztomographischen Untersuchung, ist die Ultrasonographie deutlich kostengünstiger, nicht invasiv und beliebig oft wiederholbar (Tóth und Hollerrieder 2010a). Sie gilt jedoch als wenig spezifisch und sensitiv (Gilger 2011 ). Obwohl durch die Ultrasonographie Rückschlüsse auf die Kontur und Zusammensetzung einer retrobulbären Umfangsvermehrung gezogen werden können, ist die exakte Lokalisation und Ausbreitung eines Tumors sowie dessen Typ im Ultraschall häufig nicht nachweisbar (Miller und Cartee 1985, Matiasek et al. 2007). Dies war auch bei dem hier beschriebenen Patienten der Fall.

Mit Hilfe der konventionellen Radiographie können röntgendichte Anteile der Augenregion dargestellt werden. Aufgrund der Überlagerung verschiedener Strukturen ist der Nutzen dieses bildgebenden Verfahrens bei der Diagnosefindung in dieser anatomischen Region als gering einzuschätzen. Die Anwendung kann jedoch in Fällen, in denen röntgendichte Veränderungen vermutet werden, einen diagnostischen Mehrwert haben (Tóth und Hollerrieder 2010a). In diesem Fall wurde auf eine röntgenologische Untersuchung verzichtet, da in der Ultrasonographie eine weichteildichte Struktur dargestellt wurde und ein zusätzlicher Informationsgewinn nicht zu erwarten war.

An diesem Punkt kann eine computertomographische oder magnetresonanztomographische Untersuchung des Schädels weitere Aufschlüsse geben. Bei beiden Verfahren werden Bilder unterschiedlicher Ebenen des zu untersuchenden Körperteils erstellt, die eine präzise Darstellung der anatomischen Strukturen ohne Überlagerungen erlauben. Auf diese Weise wird ein enormer Informationsgewinn über Lokalisation und Ausdehnung einer retrobulbären Umfangsvermehrung ermöglicht, der von großer Bedeutung für das weitere therapeutische Vorgehen sein kann (Wollanke et al. 2006). Mit Hilfe der Magnetresonanztomographie lässt sich insbesondere Weichteilgewebe exzellent darstellen (Arencibia et al. 2000, Gerlach und Gerhards 2008). Eine Beteiligung von Nervus opticus, Bulbus und Knochen am neoplastischen Geschehen sollte nach Matiasek et al. (2007) präoperativ ausgeschlossen werden. Dies erfolgte im vorliegenden Fall mittels 3 Tesla MRT. Die Magnetresonanztomographie führte daher zu dem Schluss, dass die Möglichkeit eines chirurgischen Vorgehens unter Erhalt des Auges bestand. Die gesamte retrobulbäre Ausdehnung der Umfangsvermehrung konnte dargestellt werden, so dass eine exakte Operationsplanung möglich war.

Obwohl die Magnetresonanztomographie Aufschlüsse über den Charakter der einzelnen Gewebe gibt (Wollanke et al. 2006, Gerlach und Gerhards 2008), existieren in der Bildgebung nur wenige Kriterien für die Differenzierung in benigne und maligne Neoplasien (Gerlach und Gerhards 2008). Gerlach et al. (2007) beschreiben die MRT-Untersuchung von drei Pferden mit Melanomen im Kopfbereich, von denen eines retrobulbär lokalisiert war. Die Melanome fielen durch eine erhöhte Signalintensität in T1-gewichteten Sequenzen und ein erniedrigtes Signal in T2-gewichteten Sequenzen auf. Die Autoren beschreiben Melanome damit als differenzierbar im MRT. Dieses eindeutige (melanotische) Muster traf im vorliegenden Fall jedoch nicht uneingeschränkt zu, insbesondere weil sich in den T2-Sequenzen eine inhomogene Signalintensität abzeichnete. In der humanmedizinischen Literatur werden sehr unterschiedliche magnetresonanztomographische Muster von Melanomen beschrieben (Hammersmith et al. 1990, Isiklar et al. 1995), so dass die Verdachtsdiagnose "primäres Melanom", die nach der magnetresonanztomographischen Untersuchung gestellt wurde, verifiziert werden sollte.

Für eine sichere Gewebedifferenzierung wird eine histopathologische Untersuchung empfohlen (Basher et al. 1997, Gilger 2011). Aus diesem Grund wurde im vorliegenden Fall direkt nach der magnetresonanztomographischen Untersuchung in derselben Allgemeinanästhesie ein Bioptat unter ultrasonographischer Kontrolle aus dem Bereich der retrobulbären Umfangsvermehrung entnommen. Zu beachten ist, dass die mechanische Irritation mit einer Biopsienadel im Fal- 
le eines Melanomes zu einer Stimulation abnormaler Melanozyten in direkter Nähe oder zu einer Verschleppung von Tumorzellen in nicht betroffenes Gewebe führen kann. Dies löst möglicherweise ein erneutes, starkes Tumorwachstum aus (Pascoe und Knottenbelt 1999). Deshalb ist es außerordentlich wichtig, Nutzen und Risiken einer derartigen Manipulation abzuwägen und den Besitzer über etwaige Risiken aufzuklären. Erst die genave Identifikation des retrobulbären Prozesses ermöglichte den Ausschluss einer Neoplasie anderer Histogenese, beispielsweise eines neuroendokrinen Karzinoms. Diese Tumorart gehört beim Pferd zu den am häufigsten vorkommenden Neoplasien der Orbita (Gilger 201 1). In einem solchen Fall wäre die Prognose sehr vorsichtig gewesen, da bei Erreichen des Gehirns innerhalb kurzer Zeit mit Ausfallserscheinungen zu rechnen wäre und eine Therapie als infaust angesehen wird (Wollanke et al. 2006). Dementsprechend wurde der Nutzen, die Art der Umfangsvermehrung zu identifizieren und damit eine bessere prognostische Einschätzung zu treffen, größer eingeschätzt, als unter Umständen ein weiteres Tumorwachstum zu induzieren.

Bei dem im vorliegenden Fall histopathologisch nachgewiesenen Melanom handelte es sich um einen benignen Tumor der Melanozyten, der raumfordernd, aber nicht invasiv wuchs. Melanome sind meist Hauttumoren, die an diversen Lokalisationen des Körpers vorkommen können. Die Orbita stellt aber eine eher untypische Tumorlokalisation dar (McMullen et al. 2008). Vor allem bei Schimmeln ab einem Alter von 6 bis 8 Jahren treten Melanome auf und wachsen langsam (Pascoe und Knottenbelt 1999). Bei der Stute in dem vorliegenden Fall handelte es sich um einer ältere Schimmelstute, die zusätzlich an der typischen Region unter der Schweifrübe einen weiteren, pigmentierten, derben Knoten in der Haut aufwies, bei dem es sich sehr wahrscheinlich auch um ein Melanom handelte.

In der Literatur sind nach Kenntnis der Autoren nur drei Fälle von retrobulbären Melanomen beschrieben (Sweeney und Beech 1983, Wollanke et al. 2006, Gerlach et al. 2007). Dabei handelte es sich jeweils um Schimmel, die älter als 14 Jahre waren. Die langsam wachsenden Tumoren führten zu Vorwölbungen des retrobulbären Fetts in der Fossa supraorbitalis und Exophthalmus. Zusätzlich zeigten zwei der drei Tiere eine Schwellung im Bereich des Musculus masseter auf der betroffenen Seite. Die Diagnose Melanom wurde nach chirurgischer Entfernung auf der Grundlage der typischen Gewebemerkmale (Wollanke et al. 2006, Gerlach et al. 2007) bzw. durch histopathologische Untersuchung eines Bioptates gestellt (Sweeney und Beech 1983). Im letzten Fall wurde das Melanom nicht chirurgisch entfernt. Das Tier zeigte 26 Monate nach der Erstvorstellung eine Progression des Exophthalmus. Visus, Pupillarreflex und Drohreaktion waren noch erhalten, während die Anzahl der retinalen Gefäße im Vergleich zur gesunden Seite bereits zurückgegangen war. Eine Expositionskeratopathie wurde daverhaft mit antibiotischer Augensalbe behandelt (Sweeney und Beech 1983). Dieser Fall zeigt, dass ein Pferd auch ohne ein chirurgisches Eingreifen überleben kann. Das Wachstum des Melanoms schreitet jedoch mit hoher Wahrscheinlichkeit voran, so dass immer mit sekundären Komplikationen gerechnet werden muss. Daraus resultiert eine engmaschige medizinische Überwachung, um im Bedarfsfall palliativ eingreifen zu können.
Die Entfernung des retrobulbär gelegenen Melanoms wurde im vorliegenden Fall über eine dorsale Orbitotomie ohne Durchtrennung des Arcus zygomaticus vorgenommen. Dieser Zugang wurde bereits von Basher et al. (1997) zur Entfernung eines neuroendokrinen, retrobulbär gelegenen Tumors beschrieben. Die Orbitotomie ist indiziert, wenn Fremdkörper, umschriebene Tumoren, Zysten oder Abszesse unter Schonung des Bulbus entfernt werden sollen (Tóth und Hollerrieder 2010c, Gilger 2011). Zu den Risiken der Orbitotomie zählt die Traumatisierung des Auges und seiner Adnexe sowie Schädigungen von Ästen des N. auriculopalpebralis während der Operation. Die detaillierte Planung des operativen Vorgehens anhand der magnetresonanztomographischen Darstellung macht dieses Risiko besser einschätzbar und wird von Gilger (2011) dringend empfohlen, um das Ausmaß der Neoplasie vollständig zu erfassen und den bestmöglichen operativen Zugang zu wählen. Dennoch ist die normalanatomische Situation durch den raumfordernden Prozess stark verändert, so dass z. B. der Verlauf der Äste des N. auriculopalpepralis erheblich vom zu erwartenden Verlauf abweichen kann. Die größtenteils stumpfe Präparation trägt hier zu einer bestmöglichen Schonung des Gewebes bei.

Der partielle Funktionsverlust des Oberlides ist vermutlich auf eine Schädigung einzelner Nervenäste durch Dehnung, Druck oder Manipulation zurückzuführen. Die Funktion des Oberlides wird durch zwei Muskeln aufrechterhalten. Dies sind $\operatorname{der}$ M. levator palpebrae superioris, dessen Innervation über den N. oculomotorius erfolgt, und der M. levator anguli oculi medialis, der durch den Ramus zygomaticus des $\mathrm{N}$. auriculopalpebralis innerviert wird (Wissdorf et al. 2010). Letztgenannter erscheint unbeeinträchtigt, da er für das Heben des medialen Anteils des Oberlides zuständig ist und dies bei der Stute postoperativ uneingeschränkt möglich war. Der in der Tiefe verlaufende N. oculomotorius kann durch das raumfordernde Melanom an sich oder durch die Manipulation während der Operation geschädigt worden sein. $\mathrm{Ob}$ es sich dabei um eine permanente Beeinträchtigung handelt oder ob es zu einer schleichenden Verbesserung kommt, ist nicht vorhersehbar.

Postoperativ bestand im beschriebenen Fall die Gefahr eines Rezidivs und einer Metastasierung des Melanomes, die auch deswegen erhöht war, weil die Tumorkapsel intraoperativ rupturierte und die Neoplasie nicht in toto entfernt werden konnte. Der Verbleib von Tumorzellen im Gewebe sowie eine Stimulation abnormaler Melanoblasten im Operationbereich können zu einem erneuten und schnelleren Tumorwachstum führen (Pascoe und Knottenbelt 1999). Dem wurde im vorliegenden Fall mittels Injektion von 5-Fluorouracil in das Wundbett vorgebeugt. Der intraoperativ rupturierte Anteil des Melanoms war durch derbes Gewebe mit dem Processus zygomaticus fest verbunden und ließ sich daher nicht in toto entfernen. Diese feste Verbindung wurde bereits nach Auswertung der magnetresonantomographischen Bilder vermutet. Ein alternativer operativer Zugang für eine Orbitotomie ist beschrieben und beinhaltet die temporäre Resektion von Anteilen von Arcus und Processus zygomaticus (Goodhead et al. 1997). Auch bei diesem Zugang hätte jedoch im vorliegenden Fall eine Ruptur des Melanoms nicht sicher verhindert werden können, da eine Verbindung zum Knochen im Bereich des Processus zygomaticus vorlag. Aus diesem Grund wurde der weniger invasive Zugang ohne Orbitotomie gewählt. 